\title{
A Study of the Relative Clause as a Modifier in Two Ghanaian Newspapers
}

\section{Gordon Senanu Kwame Adika}

\author{
Language Centre, University of Ghana, Legon, Ghana
}

Email: adika@ug.edu.gh

\section{Ernest Kwesi Klu}

\author{
Department of English, University of Venda, Thohoyandou, South Africa
}

Email: asongkwesi@gmail.com

\section{Doi:10.5901/mjss.2014.v5n20p2943}

\begin{abstract}
This article investigates the use of the relative clause as a modifier in two major Ghanaian newspapers - Daily Graphic and Daily Guide. Specifically, it examines how the three main relative clauses; namely, defining, non-defining and sentential have been used in the selected newspapers. Analyzing data drawn from both newspapers from 1st June - 30th November, 2011, we discovered that both newspapers contained violations of the syntactic and semantic rules with regard to the use of relative clauses. These violations, we argue, could create potential sources of confusion for the reader in the interpretation of the sentences. The paper describes the nature of the violations and recommends that editors pay greater attention to this aspect of written communication. Furthermore, language courses in schools and institutes of journalism as well as universities in Ghana should pay substantial attention to the teaching of relative clauses as modifiers.
\end{abstract}

Keywords: relative clause, modifiers, newspapers, ambiguity, antecedents

\section{Introduction}

Newspapers (as public communication channels) constitute a pivotal conduit of education for the citizenry of any country. They not only disseminate information but also represent a critical part of the development dialogue and governance. Along with this comes, on one side, the responsibility of newspapers to ensure that the language used in this dialogue is standard and unambiguous; and on the other side, the expectation from intended readers that the quality of language use would be high in terms of grammaticality and felicity norms. However, this expectation is not always met especially in English-speaking countries of West Africa like Nigeria and Ghana, where English is the official language and the language of most of the major newspapers in the country, due in part to the inevitable language proficiency differentials among the contributors to the newspapers (Jowitt, 1994; Tingley 1981).

In Ghana, for example, evidence of the inadequacies in the language of newspapers has been well documented (see for example, Fosu, 2011; Nimako, 2004; Denkabe \& Gadzekpo, 1996). However, specific studies on inadequacies in the area of relative clauses concerning the language of newspapers are hard to find. Admittedly, the relative clause as a modifier has been researched extensively, especially in relation to sentence processing and how readers (native and non-native) resolve ambiguities associated with its use (Pan et al., 2014; Izumi, 2003; Spivey-Knowlton et al., 1993). Some studies have entailed crosslinguistic analysis between English, on one hand and languages like Spanish, Hungarian, and Japanese on the other (Fernandez, 2003; MacWhinney \& Pleh, 1988; Miyamoto \& Nakamura, 2003). However, studies on the use of relative clauses in newspapers especially in second language contexts like in Nigeria and Ghana are hard to find, and the few that have focused on relative clauses have not dwelt on felicity of usage. Wiredu (2012), for instance, comprehensively examines the types and contexts of use of relative clauses in Ghanaian newspaper editorials. Nevertheless, his analysis dwells mainly on function and distribution and not on correctness or otherwise of usage.

This study, therefore, attempts to identify and describe the nature of the errors involving the use of the relative clause in modification in Ghanaian newspapers. The specific research questions are: (a) How are the three main types of relative clauses - defining, non-defining and sentential as modifiers used in Ghanaian newspapers?; and (b) What specific errors characterize the usage? 


\section{The Relative Clause as a Modifier}

In English grammar, relative clauses fall under the general area of modifiers which encompass determiners, adverbs, adjectives, nouns, phrases and clauses (Ebest et al., 2000; Quirk \& Greenbaum, 2000; Leech \& Svartvik, 2013). In most cases, grammatical elements such as "articles" and "determiners" - $a$, an, the, few, a few, some, each, each other and one another - are also added to the class of modifiers (Rao \& Ado, 2010). Modifiers may be defined as "any word or group of words used to describe a noun" (Sekyi-Baid00, 2003:503); or as "words (adjectives and adverbs) which help us clarify our ideas and make them more vivid" (Long, 2007: 647); or further as "determiners which operate as premodifiers in the structure of a noun phrase" (Thakur, 2007:32).

Within the group of modifiers, the relative clause component presents challenges to language users in both the reading and writing processes (Gibson et al., 2013). Indeed, although second language users are able to recognize relative clauses in texts, difficulties arise when they have to create or compose texts requiring this grammatical structure especially in defining and non-defining contexts (Felser et al., 2003; Celce-Murcia \& Larsen-Freman, 1999; FrenckMestre \& Pynte, 1997). The difficulties appear to relate to (a) deciding if the relative clause is essential or nonessential, and applying the appropriate punctuation; and (b) positioning the relative clause in relation to the sentence element that it modifies. This paper investigates this specific sub-group of modifiers, focusing on the three main types of relative clauses; namely, the defining, the non-defining and the sentential relative clause.

The defining relative clause provides one's listeners or readers additional information about the preceding noun, pronoun or noun phrase in a text; this information is normally essential for the identification of the antecedent (Thakur, 1987; Celce-Murcia and Larsen-Freeman, 1999); or as Pan et al. (2014:2) render it, such clauses "serve to identify a specific referent from a set of possible referents." The non-defining relative clause as a modifier on the other hand does not limit or highlight its antecedent because much information has already been given about it (Thakur, 2007; Long, 2007; Quirk \& Greenbaum, 2000). In other words, the non-defining relative clause is often used to indicate that the antecedent being referred to is the only one of its kind. Freeborn (1987: 194) identifies the non-defining relative clause as "a nonrestrictive relative clause which provides additional information about the Noun Phrase without restricting or defining it..." The third type of clause relevant to this study is the sentential relative clause, which makes reference to an entire preceding clause or sentence. For example: "The renovated museum is attracting more tourists, which means that the money spent on it is justified." In this example, the clause "which means that the money spent on it is justified" is the sentential relative clause, and its function is to comment on the entirety of the statement made in the preceding sentence.

In sum, it is pertinent to point out that if relative clauses as post-modifying elements are not used to relate to their appropriate preceding nouns and pronouns in an utterance or a sentence, it creates interpretation or ambiguity problems; that is, a situation where a modifier may refer to a set of possible antecedents. Whenever writers do not use modifiers correctly, they confuse their readers because they (the readers) have to read the text repeatedly in an effort to understand the intended message, and this inevitably frustrates them (Jungk, 2005).

\section{Data and Methodology}

A purposeful sampling method (Patton 1990; Tagoe 2009) was used to gather data from two leading Ghanaian newspapers - the Daily Graphic, a state-owned newspaper and the Daily Guide, a private-owned newspaper. The researchers read both newspapers consistently for six months from $1^{\text {st }}$ June to $30^{\text {th }}$ November in 2011 in order to identify and categorize wrong use of modifiers involving relative clauses. In all, 196 wrongly used modifiers were identified in the Daily Graphic, while 199 were discovered in the Daily Guide. However, for the purpose of this paper, the analysis covers a few examples of each type of modifiers that were infelicitously used in both newspapers.

\section{Analysis and Discussion}

This section is presented in terms of the relative clause sub-types; namely, (i) defining (ii) non-defining, and (iii) sentential relative clauses.

\subsection{Defining relative clauses}

The following excerpts are used for illustrative purposes:

i. ... high academic standard set by the school over the years which had placed it not only among the best in 
Ghana... (Daily Graphic, p. 11, June 1, 2011)

ii. ....There is hardly any married couple in Ghana who will not want to welcome their own baby... (Daily Graphic, p. 11, June 2, 2011).

iii. The National Disaster Management Organization (NADMO) has presented relief items to flood victims in Tema Newtown who were recently affected by a rainstorm (Daily Guide, p. 15, June 17, 2011).

iv. Enhancing the operations of Ghana Police Service is one promise that runs through the campaign pledges of many a political party who brandish it with relish on their campaign trails... (The Editorial, Daily Guide, p. 7, June 22, 2011)

v. ....He was a graduate of Koforidua Polytechnic who was on National Service at Sogakope in the Volta Region (Daily Graphic, p. 16, June 1, 2011).

In excerpt (i), the relative clause is positioned after a passive structure containing an explicitly mentioned agent, which is in turn followed by an adjunct:

\section{[... high academic standard set by the school (Passive Structure)] + [over the years (Adjunct)] [which had placed it not} only among the best in Ghana (Relative clause)]

The relative pronoun "which" refers to the high academic standard, and this point would be best communicated in a restructuring of the sentence using the active voice and repositioning the relative clause closer to its antecedent as in: "Over the years, the school had set a high standard which had placed it not only among the best in Ghana ..."

In excerpt (ii), the adverbial phrase "in Ghana", which can be moved around may best be placed elsewhere in order to move the relative pronoun closer to the relativized noun. This would yield, for example, "In Ghana, there is hardly any married couple who will not want to welcome their own baby." Of course the discourse context would also determine whether or not it is much more appropriate to place the adverbial phrase "In Ghana" in sentence initial position, and considering the fact that this excerpt is actually the opening sentence of a newspaper article, a restructuring that brings the adjunct "In Ghana' to initial position is desirable.

In excerpt (iii), the information in the relative clause is not new and therefore does not contribute to the development of the discourse: the noun phrase "flood victims" is synonymous with "who [reference to flood victims] were recently affected by a rainstorm." There is, thus, no point in using the relative clause in this instance.

In excerpt (iv), in order to appreciate the nature of the problem, we have to start with the feature specifications of the relative pronoun "who", which are as follows:

who + subject NP +human

(Celce-Mucia \& Larsen-Freeman, 1999:582).

Therefore, the use of "who" in this context stands in clear violation of the collocation restrictions imposed by the semantic and syntactic features of the relative pronoun "who". The more suitable pronoun for "a political party" is "that", the syntactic and semantic features of which are:

that \pm subject NP \pm human (Ibid).

Having offered this explanation, we still have to draw attention to the peculiar diction of the sentence. The words "brandish" and "relish" evoke [+human] attributes; "brandish" means "to wave something in a threatening or excited way" while "relish" refers to the "enjoyment you derive from doing something". The question is whether the metaphorical use of these words provide the relevant discourse context to warrant the selection of the relative pronoun "who". Any answer would simply be speculative. To avoid this stylistic infelicity, we have to use "that" since it carries both \pm human features. That part of the sentence should therefore read - "many a political party that brandish it with relish on their campaign trails."

A related error type (excerpt $v$ ) is the positioning of the relative pronoun in relation to the head noun. When, for example, the relative pronoun "who" does not immediately follow its antecedent which is thuman, the result is clumsiness of expression. Take for instance, the excerpt: '....He was a graduate of Koforidua Polytechnic who was on National Service at Sogakope in the Volta Region' (Daily Graphic, p. 16, June 1, 2011). This sentence can be amended to read: "... He was a Koforidua Polytechnic graduate who was on National Service at Sogakope in the Volta Region...". 


\subsection{Non-defining Relative Clauses}

The following excerpts are used for illustrative purposes:

i. Doctor Acheampong who is also the Director of Research at the Polytechnic made the declaration at a press briefing at Koforidua on August, 8, 2011... (Daily Graphic, p. 13, August 16, 2011).

ii. $\quad$...he said for past 14 years, the people of La have not been taking part of [sic.] the Homowo Festival which brings unity among the people... (Daily Guide, p. 15, June 17, 2011).

iii. ...the Bus Rapid Transit (BRT) which is anticipated to deliver fast, comfortable and cost effective urban mobility through the provision of exclusive right-of-way lanes... (Daily Guide, p.10, September 21, 2011).

In excerpt (i) above, the identity of the subject is explicit enough; therefore, the relative clause simply provides additional information about Doctor Acheampong. Commas are thus needed immediately after the noun 'Doctor Acheampong' and after 'Polytechnic' in order to signal the nonrestrictive sense in which the relative clause is being used; as exemplified by: 'Doctor Acheampong, who is also the Director of Research at the Polytechnic, made the declaration at a press briefing at Koforidua on August, 8, 2011...'

The italicized relative clauses in excerpts (ii) and (iii) should have been marked off as non-defining relative clauses because the antecedent being referred to in each case is either unique or is the only kind; therefore, no additional information is needed for the reader to be able to identify each. For example, in (ii), the 'Homowo Festival' being referred to is a unique traditional festival celebrated annually by the Gas in Ghana. Therefore, once the commas are omitted, the implication is that there are other Homowo Festivals, and such a statement is obviously erroneous. Similarly, in (iii) the 'Bus Rapid Transit' is a unique programme, which was expected to be implemented in Ghana sometime ago; in this regard then, it does not need extra information for it to be unambiguously identified or understood. For this reason, obligatory commas are needed in each case to signal the non-restrictive meaning being conveyed.

\subsection{Sentential Relative Clauses}

The following excerpts are used for illustrative purposes:

i. Also, in spite of limitations imposed by the dismal mental health financing institution in Ghana which is characterized by low budgetary allocation... (Daily Graphic, p. 19, August 17, 2011).

ii. ... currently, the NHIA is said to be heavily indebted to the service providers which is having adverse effects on their businesses... (Daily Guide, p. 19, August 4, 2011).

iii. The two, in the past few months, have come under immense criticism and attack in the Hohoe-North Constituency which led to the dismissal of Condobrey, who used to be the Hohoe MCE (Daily Guide, p.26, September 26, 2011).

In all the excerpts above (that is, i-iii), the commas before the sentential clauses have been omitted, depicting a lack of awareness on the part of the authors of the nature and function of sentential relative clauses. In excerpt (i), for example, the relative clause is not modifying "Ghana"; therefore, it is a sentential relative clause, but not a defining nor a non-defining one. The sentence can be corrected by placing a comma after "Ghana" as in: "Also, in spite of limitations imposed by the dismal mental health financing institution in Ghana, which is characterized by low budgetary allocation..."

Also, in excerpt (ii), the italicized relative clause should be signaled as sentential through the use of a comma after the noun "providers" to avoid ambiguity. Accordingly, the sentence can be corrected by placing a comma after "providers" as in: "... currently, the NHIA is said to be heavily indebted to the service providers, which is having adverse effects on their businesses..."

Finally, in excerpt (iii), the italicized clause should be signaled as sentential. The clause is not modifying the NP "Hohoe-North Constituency"; instead, it is modifying the entire sentence or an idea in the sentence. A comma is therefore required after the noun "Constituency" to avoid the confusion being created in the sentence. The correct sentence should be: "The two, in the past few months, have come under immense criticism and attack in the Hohoe-North Constituency, which led to the dismissal of Condobrey, who used to be the Hohoe MCE".

\section{Conclusion}

From the analysis and discussion, we can identify five main types of violation related to the use of the relative clause as a modifier. These are: 
i. Redundancy of relative clause use;

ii. Lack of clarity in the use of relative clauses embedded with passive structures;

iii. Violation of the collocation restrictions of relative pronouns;

iv. Omission of commas in non-restrictive use of the relative clause; and

v. Omission of commas before sentential clauses depicting a lack of awareness of the nature and function of sentential relative clauses.

The overall implication of the findings is that despite the status of English as an official language in Ghana since the country attained independence in 1957, its use in public spaces such as the newspaper reflects the poor state of knowledge among some educated users on some aspects of English grammar. Indeed, English major students are graduating with astonishingly low level of knowledge of English grammar (Dako et al., 1997). This situation has been attributed largely to the quality of English language teaching across the educational system (Klu 2000) which is encumbered with mammoth challenges such as inadequate textbooks, scarcity of trained teachers, and insufficiently resourced teacher training colleges.

In sum, modification plays an essential role in human communication. It offers a linguistic strategy for amplifying or limiting information provided about an element of sentence structure. However, language users, especially second language users need to master the syntactic and semantic principles governing the use of the modifiers. The case of the relative clauses is particularly important since a violation of the principles governing their use would lead to ambiguity and the distortion of information relationships within a clause complex. As we have observed, the plethora of infelicities with regard to the use of the relative clause as modifier indicate the need for greater editorial oversight as well as regular inservice training for journalists and editorial assistants. Above all, in second language contexts like the linguistic environment of Ghana, the school system, from primary through higher education should lay emphasis on that aspect of grammar which deals with modifiers and the complexities involved in relative clause ambiguity resolution.

\section{References}

Celce-Murcia M., \& Larsen-Freeman D. (1999). The grammar book: An ESL/EFL teacher's course (2nd Ed.). Boston: Heinle \& Heinle. Denkabe, A., \& Gadzekpo, A. (1996). What is fit to print? Language of the press in Ghana. Accra: Ghana Universities Press. Ebest B.S. (2000). Writing from A to Z: The easy-to-use reference handbook (3rd Ed.). London: Mayfield Publishing Company.

Felser, C. Roberts, L. Gross, R., \& Marinis, T. (2003). The processing of ambiguous sentences by first and second language learners of English. Applied Psycholinguistics, 24, 453-489.

Fernández, E. M. (2003). Bilingual sentence processing: Relative clause attachment in English and Spanish (No. 29). John Benjamins Publishing.

Fosu, M. (2011). Situating language at the centre of journalism training: the case for broadening the spheres of English teaching and learning in journalism training institutions in Ghana. Global Media Journal-African Edition, 5(1), 52-80.

Freeborn D 1987. A course book in English grammar. London: The Macmillan Press.

Frenck-Mestre, C., \& Pynte, J. (1997). Syntactic ambiguity resolution while reading in second and native languages. Quarterly Journal of Experimental Psychology, 50A, 119-148.

Gibson, E., Tily, H. \& Fedorenko, E. (2013). The processing complexity of English relative clauses. In Sanz, M., Laka, I., \& Tanenhaus, M.K. (Eds.), Language down the garden path: The cognitive biological basis for linguistic structures (pp. 149-173). Oxford: Oxford University Press.

Izumi, S. (2003). Processing difficulty in comprehension and production of relative clauses by learners of English as a second language. Language Learning, 53(2), 285-323.

Jowitt, D. (1994). The English of Nigerian newspapers. English Today, 40 (10) No.4, 23-28.

Jungk, D. (2005). Applied writing for technicians. New York: McGraw-Hill.

Klu, E.K. (2000). Issues of language, linguistics and pedagogy in the continuous professional development of teachers of English in Bushbuckridge. Unpublished D.Ed thesis, Johannesburg: Rand Afrikaans University.

Leech, G. \& Svartvik, J. (2013). A Communicative Grammar of English. (3rd Ed.). Routledge.

Long CE 2007. College writing resources: with readings. New York: Pearson Education.

MacWhinney, B., \& Pleh, C. (1988). The processing of restrictive relative clauses in Hungarian. Cognition, 29(2), 95-141.

Miyamoto, E. T., \& Nakamura, M. (2003). Subject/object asymmetries in the processing of relative clauses in Japanese.

In Garding, G., \& Tsujimura, M. (Eds.). Proceedings of the 22nd WCCFL (pp. 342-355). Somerville, MA: Cascadilla Press.

Nimako, A. (2004). Mind your language: Educated Ghanaian English. Tema: Ronna Publishers.

Pan, H., Schimke, S., \& Felser, C. (2014). Referential context effects in non-native clause ambiguity resolution. International Journal of Bilingualism, $\mathrm{XX}(\mathrm{X}), 1-16$.

Patton, M. (1990). Qualitative Evaluation Methods. (2nd Ed.) Thousand Oaks, CA: Sage.

Quirk, R., \& Greenbaum, S. (2000). A University Grammar of English. Edinburgh: Pearson Education. 
Rao N.D.V., \& Ado, D.S. (2010). Student's Companion: A Foundation Course in English for Senior High Schools and Colleges. India: Rajendra Ravindra.

Sekyi-Baidoo, Y. (2003). Learning and Communicating (2nd Ed.). Accra: Infinity Graphic.

Spivey-Knowlton, M. J., Trueswell, J. C., \& Tanenhaus, M. K. (1993). Context effects in syntactic ambiguity resolution: Discourse and semantic influences in parsing reduced relative clauses. Canadian Journal of Experimental Psychology/Revue canadienne de psychologie experimentale, 47(2), 276.

Tagoe, M. (2009). A handbook for writing research proposals. Accra: Adwinsa Publications.

Thakur, D. (1987). A handbook of English grammar and usage. New Delhi: Bharati Bhawan Publishers.

Thakur. D. (2007). Linguistics simplified: syntax. New Delhi: Bharati Bhawan Publishers.

Tingley, C. (1981). Deviance in the English of Ghanaian newspapers. English World-Wide, 2(1), 39-62. Wiredu, J. F. (2012). A grammar of newspaper editorial language: the complex sentence. Legon Journal of the Humanities, 23, 75-124. 